\title{
High-finance approach to protecting tropical forests
}

\section{Washington}

IN one stroke, Bolivia last week reduced its external debt by $\$ 650,000$ and protected 3.7 million acres of tropical forest. The twin achievements came as part of a deal with Conservation International, an environmental organization, which purchased the Bolivian debt in exchange for the land protection agreement. Bolivia also agreed to endow a fund worth $\$ 250,000$ in local currency to pay for management of the newly protected land.

Countries with large external debts have sought to increase exports as a way to obtain cash for making loan payments,

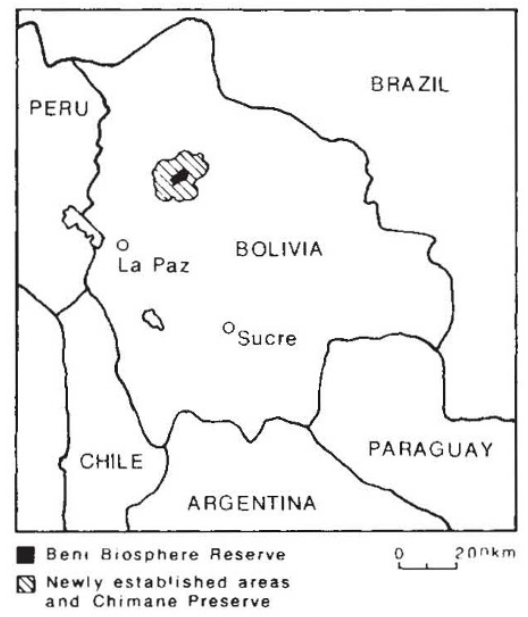

often by clearing forests for cash crops and additional agricultural land. But conservation groups have been trying to prevent countries from exploiting irreplaceable natural resources. The 'debt-for-nature' exchange appeals to many as a solution.

In the Bolivian example, Conservation International bought the $\$ 650,000$ note at an 85 per cent discount using a $\$ 100,000$ grant from the Frank Weden Foundation. The foundation is giving $\$ 100,000$ to the World Wildlife Fund to make a similar arrangement with Costa Rica.

The newly protected region in Bolivia surrounds the Beni Biosphere Reserve, a 334,200 -acre tract established in 1982. The reserve supports 13 of Bolivia's 18 endangered species. The new reserve is protected by congressional law, as opposed to the administrative decrees that formerly covered the Beni Reserve.

Other approaches are being pursued in the US Congress. Last week, Representative John Porter (Republican, Illinois) introduced the Tropical Forest Protection Act of 1987. The bill would initiate two three-year World Bank pilot programmes to discourage damage to forests. In one programme, loans would be made to induce sustainable use of tropical forests, such as rubber-tapping or nut-farming. The other would suspend debt payments in exchange for establishing conservation easements. The bill also requires the US Secretary of the Treasury to conduct a study of the status of tropical forests. According to Porter's staff, the World Bank has been enthusiastic about the bill, and Porter is optimistic about its chances of being passed. Similar legislation is being introduced in the Senate.

The heavy discounting of debts from developing countries has opened another channel. Barbara Bramble of the National Wildlife Federation says some country's debts are discounted by 90 per cent. She is promoting legislation to allow banks to write off their loans, claiming a tax reduction for the whole loan rather than the market value. In exchange, the debtor countries would take steps to protect their natural resources. Bramble admits, however, that this scheme will go only a little way towards reducing the external debt of more than $\$ 1$ million million of developing nations.

Some countries have taken their own steps. On 25 July, Costa Rica will open the Guanacaste National Park, located on the Santa Elena peninsula in the northwest corner of the country. The park will include 32,500 acres obtained as part of a programme run by the Costa Rican National Park Foundation to purchase Costa Rican debt in exchange for enlarging and rnanaging national parklands.

Joseph Palca

\section{Sarawak's tropical rainforests exploited by Japan}

\section{Tokyo}

JAPAN has used overseas aid to help finance the exploitation of Sarawak's tropical rainforests. Evelyne Hong, a Malaysian anthropologist, revealed last week that the Japanese International Cooperation Agency (JICA) provided a $¥ 200$ million ( $\$ 1.3$ million) soft loan in 1982 to build a logging road and bridge in the Limbang district of Sarawak where more than 70 per cent of the forests have been earmarked for logging, largely for export to Japan.

Hong visited Japan to publicize the plight of the Penan, a tribe of 5,000-6,000 nomadic hunters who live in the logging area and depend on the forest for their livelihood. During the period 1963-85, 2.8 million hectares, or 30 per cent of Sarawak's total forest area, were logged and in 1984 a further 5.8 million hectares were licensed out. In a last-ditch effort to try to stop the wholesale destruction of their forest, the Penan are manning barricades across several of the logging roads, including that built with Japanese aid.

More than 80 per cent of Japan's hardwood imports come from Malaysia, about 40 per cent from Sarawak. Much of the imported wood is used for disposable panelling for forming concrete during construction work. Japan's planned construction projects, such as the Tokyo Bay bridge, may lead to increased hardwood imports and more rapid depletion of Sarawak's forests. Imports from Sarawak have risen dramatically recently partly because other countries such as Indonesia and the Philippines have clamped down on the export of unprocessed logs Japan levies import tariffs on processed timber and most imports are raw logs.

Most of the logging concessions in Sarawak, valued at thousands of millions of dollars, are owned by close relatives of leading state politicians, and the Penan have had to go to the federal government in Kuala Lumpur to appeal their case.

Hong is concerned that Japan's recent promises drastically to increase overseas development aid may result in more projects of dubious value to local inhabitants. The Limbang logging road was built with a 10-year loan from JICA; Foreign Ministry officials admit that no environmental impact study was carried out before or after road construction. The Penan claim that the logging operations have destroyed their traditional hunting grounds and that run-off from the logged areas has led to pollution and silting of the rivers.

The construction of the Batang Ai Dam in Sarawak, which destroyed more than 20,000 acres of forest and caused the displacement of thousands of natives, was financed by, among others, the Asian Development Bank (to which Japan is the major contributor), the Overseas Economic Corporation Fund of Japan and Mitsui Trust and Banking Company. The chief contractors were Maeda and Okumura construction companies of Japan.

The Environment Agency (of Japan) is considering legislation for the environmental impact assessment of overseas development projects but is not expected to take action for several years. The International Tropical Timber Organization has set up headquarters in Yokohama with a mandate to protect tropical rainforests but has been struggling to start operations on limited funds (see Nature 328, 537; 1987). Meanwhile the Penan, who set up their first blockade in March and are now manning twelve, have vowed to block the roads "until they die".

David Swinbanks 